\title{
Correction: Clinical profile and prognostic factors of alcoholic cardiomyopathy in tribal and non-tribal population
}

Dundung A, Kumar A, Guria RT, et al. Clinical profile and prognostic factors of alcoholic cardiomyopathy in tribal and non-tribal population. Open Heart 2020;7:e001335.

Author name Ajit Dundung has been corrected to Ajit Dungdung.

Open access This is an open access article distributed in accordance with the Creative Commons Attribution Non Commercial (CC BY-NC 4.0) license, which permits others to distribute, remix, adapt, build upon this work non-commercially, and license their derivative works on different terms, provided the original work is properly cited, appropriate credit is given, any changes made indicated, and the use is non-commercial. See: http://creativecommons.org/licenses/by-nc/4.0/.

(C) Author(s) (or their employer(s)) 2020. Re-use permitted under CC BY-NC. No commercial re-use. See rights and permissions. Published by BMJ.

Open Heart 2020;7:e001335corr1. doi:10.1136/openhrt-2020-001335corr1

D) Check for updates 